\title{
Morphological and seismic characteristics of the Kaoping Submarine Canyon
}

\author{
Char-Shine Liu ${ }^{a}$, Neil Lundberg ${ }^{b}$, Donald L. Reed ${ }^{c}$ and Yen-Liu Huang ${ }^{d}$ \\ ${ }^{a}$ Institute of Oceanography, National Taiwan University, Taipei, Taiwan, ROC \\ ${ }^{\mathrm{b}}$ Department of Geology, Florida State University, Tallahassee, FL 32306, USA \\ ${ }^{-}$Department of Geology, San Jose State University, San Jose, CA 95192, USA \\ 'Department of Geology, National Taiwan University, Taipei, Taiwan, ROC
}

(Received July 6, 1992; revision accepted December 4, 1992)

\begin{abstract}
Liu, C.-S., Lundberg, N., Reed, D.L. and Huang, Y.-L., 1993. Morphological and seismic characteristics of the Kaoping Submarine Canyon. Mar. Geol., 111: 93-108.

SeaMARC II side-scan sonar images and swath bathymetry plus 6-channel seismic reflection profiles reveal details of major canyons in the submarine portion of the Taiwan collision belt. The Kaoping Submarine Canyon is the largest of these, extending over $240 \mathrm{~km}$ from the mouth of the Kaoping River across the accretionary wedge to the Manila Trench. Morphological features and structural settings vary along the course of the Kaoping Submarine Canyon, defining three sections. The first section extends southwest from the mouth of the Kaoping River, cutting across the shelf and upper slope roughly perpendicular to local bathymetric contours, to about $22^{\circ} 03^{\prime} \mathrm{N}$, where the canyon turns sharply southeast. From this point, the second section of the canyon follows the trace of a major thrust fault, paralleling local structure to $21^{\circ} 35$ ' $\mathrm{N}$, at which point the canyon turns southwest again. Over the third section the canyon meanders, cutting through low-relief fault-bend anticlines and distributing orogenic sediments in intervening slope basins, to where it joins the Manila Trench. Seismic profiles reveal that this canyon, which forms a major sediment conduit between the Taiwan mountain belt and the Manila Trench, has a complicated evolutionary history, and that its development has been controlled strongly by accretionary structural processes.
\end{abstract}

\section{Introduction}

The origin and evolution of submarine canyons, which play an important role in transporting sediment to the deep sea, have long been controversial. After over 50 years of investigation of numerous submarine canyons all over the world, Shepard (1981) concluded that submarine canyons are of composite origin and may well result from long periods of formation. Most of the well-studied submarine canyons are located along passive continental margins, such as the Congo Submarine Canyon (Shepard and Emery, 1973), the Wilmington Submarine Canyon (McGregor et al., 1982), submarine canyons in the Bering Sea (Carlson and Karl, 1988) and the Mississippi Canyon (Goodwin and Prior, 1989). Their evolutions may be quite different from those located along tectonically active margins. For example, Nagel et al. (1986) suggested that besides commonly mentioned eustatic and erosional processes, tectonic processes could have been instrumental in the origin and evolution of the Ascension Submarine Canyon system, located along a strike-slip continental margin off central California. The Kaoping Submarine Canyon, which lies over the active accretionary wedge off southwest Taiwan, is likewise heavily influenced by tectonic processes.

The existence of a major submarine canyon at the mouth of the Kaoping River (then called Shimotamsui River) was first reported by Yabe and Tayama (1928). Ma (1947) compiled a bathymetric chart showing the distribution of submarine valleys around southern Taiwan and discussed their geological significance. Due to limited deepwater soundings, the submarine canyon that 
extends from the Kaoping River (named the Kaoping Submarine Canyon in this study) was thought to end about $40 \mathrm{~km}$ from the coastline (see fig. 1 of Ma, 1947). Recently, Yu et al. (1991) have reexamined the morphology of the head of the Kaoping Canyon with new bathymetric and $3.5 \mathrm{kHz}$ profiles and a 24-channel seismic profile. However, their study is also limited to about $40 \mathrm{~km}$ from the shoreline. The complete picture of the Kaoping Canyon was not recognized until the area was recently surveyed using the SeaMARC II swath-mapping system.

In May/June of 1990, a marine geophysical survey was carried out using R/V Moana Wave to investigate the propagating arc-continent collision zone off southern Taiwan (Fig. 1). This cruise (MW9006) collected SeaMARC II side-scan sonar images and swath bathymetry data, 6-channel digital seismic reflection and $3.5 \mathrm{kHz}$ profiles, and underway gravity and magnetic data concurrently

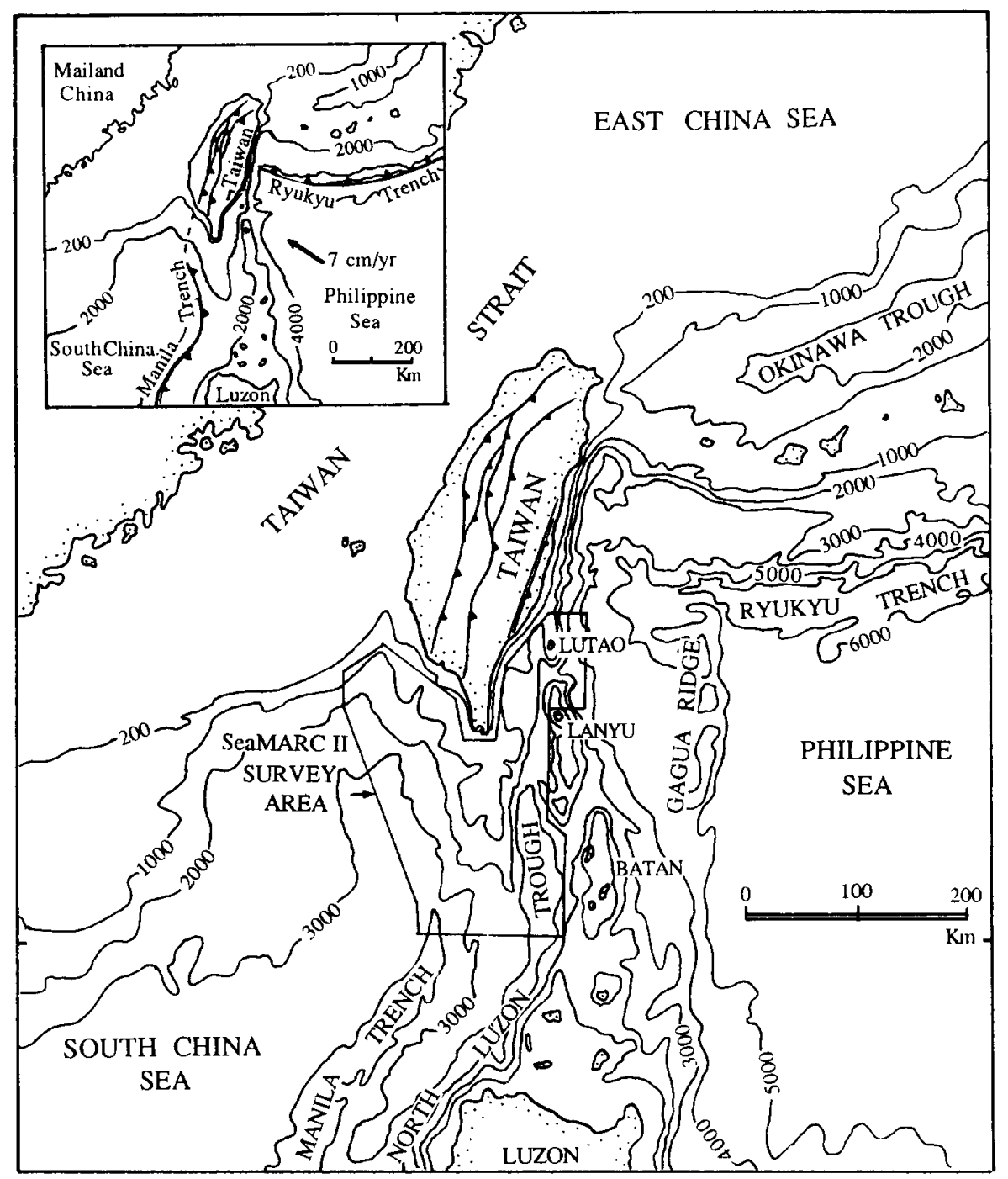

Fig. 1. Tectonic setting and bathymetry of the Taiwan arc-continent collision, showing area of SeaMARC II survey located south of Taiwan. Inset: Plate boundaries near Taiwan. Note that submarine accretionary prism expands northward to become the 4-km high mountain range of Taiwan. Modified from Suppe (1984). 


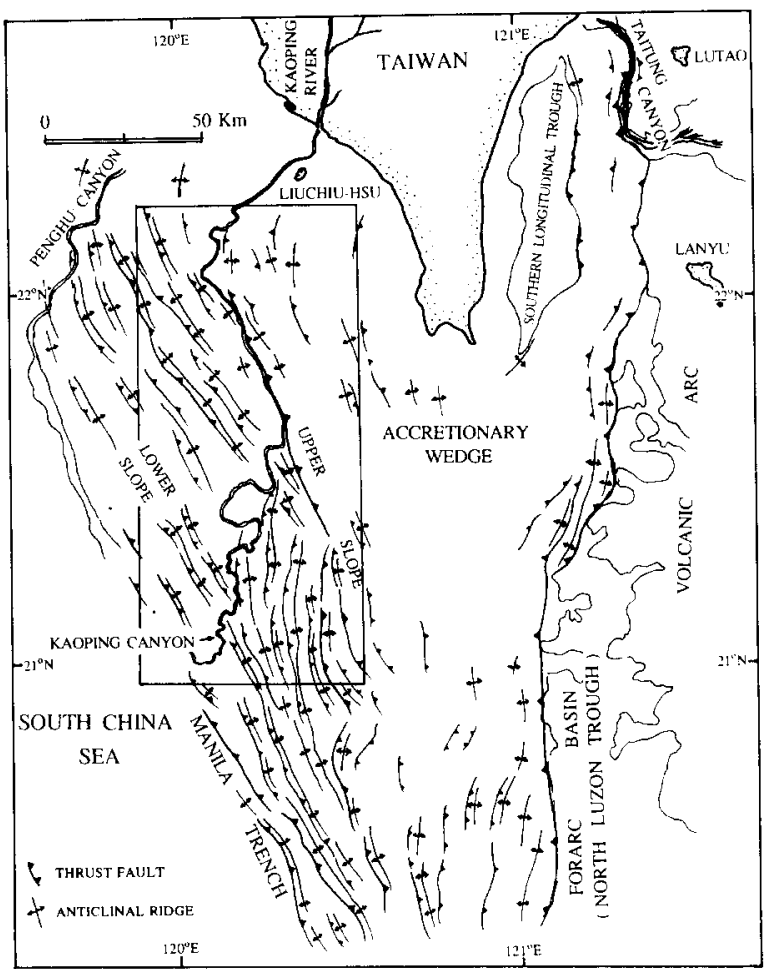

Fig. 2. Structural map of the accretionary wedge off southern Taiwan, derived from side-scan sonar image and seismic reflection profiles. Box shows location of Fig. 6 .

over about $50,000 \mathrm{~km}^{2}$ of seafloor. Complex patterns of active submarine canyons and channels over the Taiwan accretionary wedge and the Luzon volcanic arc are revealed in detail by SeaMARC II side-scan sonar images (Lundberg et al., 1990). Among numerous submarine canyons and channels off southern Taiwan, the Kaoping Submarine Canyon is the longest, extending over $240 \mathrm{~km}$ from the mouth of the Kaoping River to the Manila Trench, crosscutting morphotectonic structures of the accretionary wedge (Figs. 2 and 3 ).

In this paper we present data documenting morphologic features and structural variations of the Kaoping Submarine Canyon based on analysis of SeaMARC II side-scan sonar images and swath bathymetry, multichannel (both 24-channel and 6-channel) seismic reflection profiles, and $3.5 \mathrm{kHz}$ profiles. It has been suggested (Ma, 1963; Yu et al., 1991) that subaerial erosion is the most likely cause of the inception of the Kaoping Canyon. Our data reveal that the canyon has experienced a rather

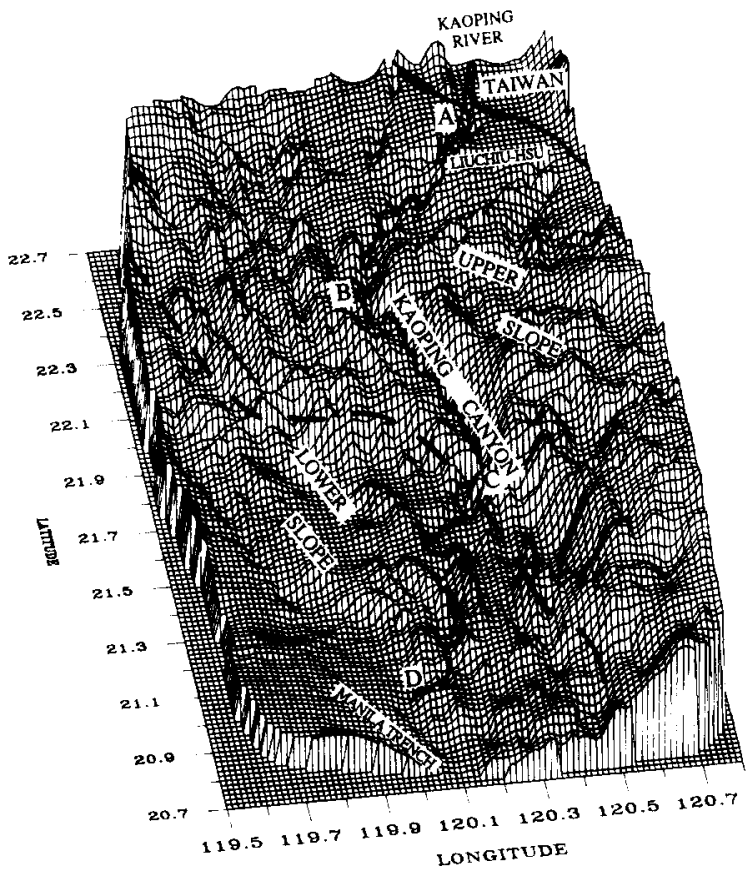

Fig. 3. Seafloor physiography of accretionary wedge off southwest Taiwan, showing Kaoping Submarine Canyon axis (heavy line). Dashed line marks the boundary between high-relief upper slope and low-relief lower slope. Locations labeled $A, B$, $C$ and $D$ delimit three sections of the Kaoping Submarine Canyon (see text for description).

\section{Canyon Axis Depth Profile}

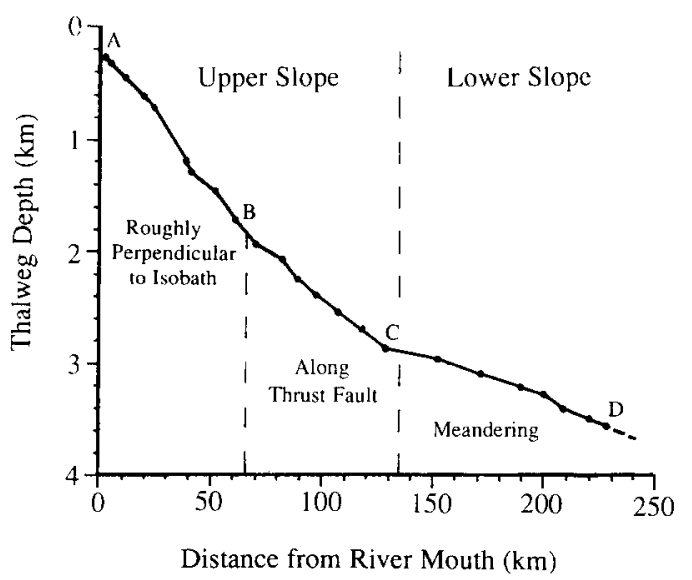

Fig. 4. Longitudinal profile of Kaoping Canyon axis, showing distinct break in slope at base of upper slope (see Fig. 3 for locations labeled $A, B, C$ and $D$ ). 


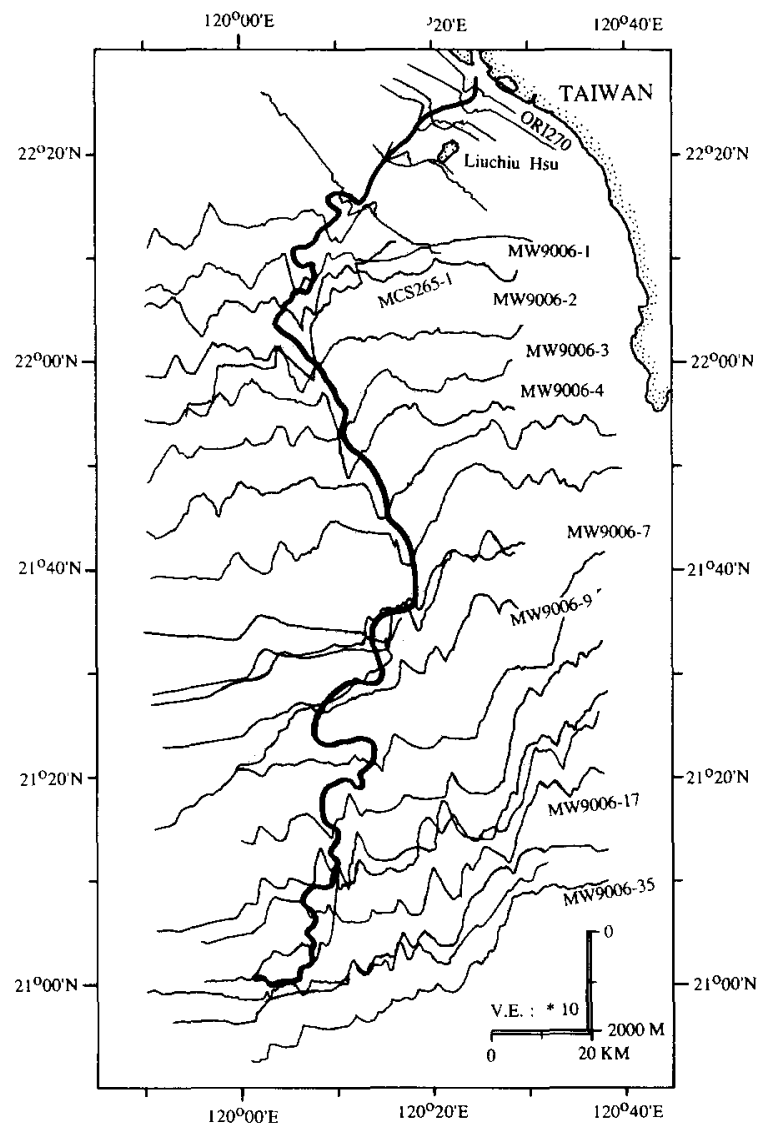

Fig. 5. Selected bathymetric transects across Kaoping Submarine Canyon. Projected bathymetry profiles (thin lines) are plotted along corresponding ship tracks (dotted lines). Bold line marks the surface location of canyon axis.

complicated history, and that a number of episodes of cutting and filling having shaped the canyon morphology. We suggest that the Kaoping Submarine Canyon is more likely to have formed by submarine processes. Our study also suggests that the development of this canyon and the distribution of detrital sediment along the canyon path are strongly affected by tectonic structures of the accretionary wedge.

\section{Tectonic setting}

The island of Taiwan is situated at the juncture of the Ryukyu and Luzon island arcs along the western margin of the Philippine Sea (Fig. 1) and is the location of an active arc-continent collision (Big, 1973; Karig, 1973; Bowin et al., 1978; Ho,
1982, 1986; Suppe, 1984; Teng, 1990; Huang et al., 1992). The Taiwan mountain belt formed initially about 5 million years ago as a result of oblique collision of the Luzon island arc with the Chinese continental margin (Buchovecky and Lundberg, 1988; Teng, 1990; Dorsey, 1992), and is actively propagating to the south (Suppe, 1987). The area off southern Taiwan represents the propagating tip of the collision, comprising the accretionary wedge between the Manila Trench to the west and the North Luzon Trough (forearc basin) and Luzon volcanic arc to the east.

The frontal portion of the submarine fold-andthrust belt is located along the western flank of the accretionary wedge. SeaMARC II side-scan sonar images and seismic reflection profiles reveal a strong structural fabric trending NW-SE offshore southwest Taiwan, which rotates to a more N-S trend further south (Lundberg et al., 1991). The Kaoping Submarine Canyon is one of the major features observed in this submarine foldand-thrust belt (Fig. 2).

\section{Morphological features}

We have investigated the detailed morphology of the Kaoping Submarine Canyon by analyzing SeaMARC II side-scan sonar images and swath bathymetry from the Moana Wave survey, supplemented by a total of $323.5 \mathrm{kHz}$ profiles, both from this survey and from cruises by the $R / V$ Ocean Researcher I (ORI236, ORI256, ORI265, ORI270, and ORI286) and the R/V Jean Charcot (POP II). Based on seafloor physiography, we have divided the frontal accretionary wedge into a highrelief upper-slope area and a low-relief lower-slope area (Fig. 3; Reed et al., 1991), a distinction that shows clearly on a longitudinal profile of the Kaoping Submarine Canyon axis (Fig. 4). The canyon extends southwesterly on the upper-slope area (section A-B in Fig. 3), from the mouth of the Kaoping River to about $22^{\circ} 03^{\prime} \mathrm{N}$ and $120^{\circ} 05^{\prime} \mathrm{E}$, where the canyon thalweg depth is about $1800 \mathrm{~m}$ (Fig. 4). The canyon then turns sharply toward the south-southeast, running almost straight (section $\mathrm{B}-\mathrm{C}$ in Fig. 3) to about $21^{\circ} 35^{\prime} \mathrm{N}$ and $120^{\circ} 18^{\prime} \mathrm{E}$, where the thalweg depth is about $2800 \mathrm{~m}$ (Fig. 4). South of $21^{\circ} 35^{\prime} \mathrm{N}$ the canyon turns to a southwest- 

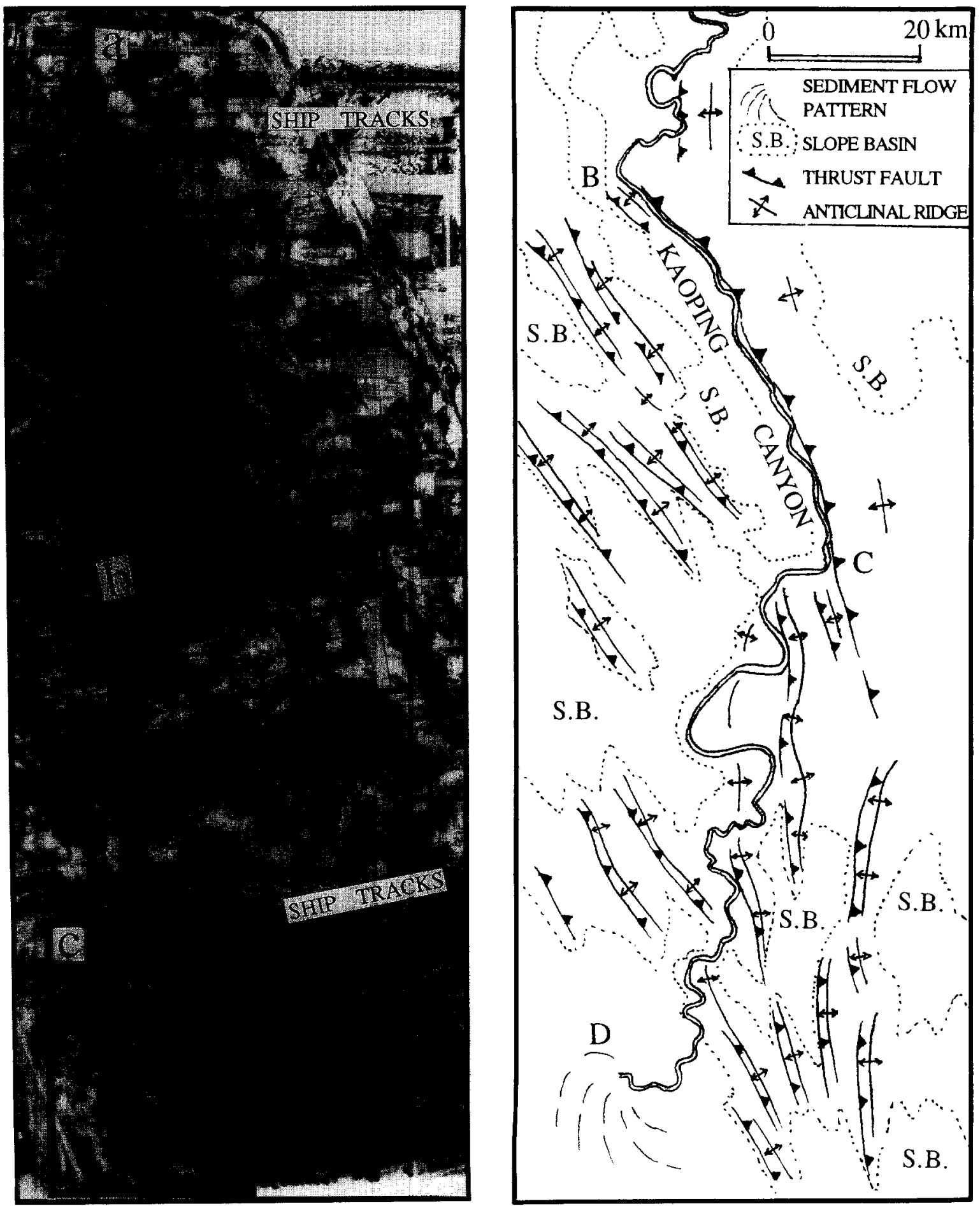

Fig. 6. SeaMARC II side-scan sonar mosaic along Kaoping Submarine Canyon and interpretative line drawing (see Fig. 2 for location). Boxes $a, b$ and $c$ indicate locations of Figs. 8, 12 and 15, respectively. 
erly course and leaves the upper-slope area. After meandering markedly across the lower-slope area (section C-D in Fig. 3), it empties into the Manila Trench at about $21^{\circ} \mathrm{N}, 120^{\circ} \mathrm{E}$, at a depth of about $3500 \mathrm{~m}$.

Selected bathymetric profiles across the Kaoping Submarine Canyon are shown in Fig. 5. The canyon morphology near the mouth of the Kaoping River is U-shaped (Fig. 5). The profile closest to the river mouth (profile ORI270 in Fig. 5) shows that the canyon cross section is only $2 \mathrm{~km}$ wide and about $200 \mathrm{~m}$ deep, below a 30 -m deep seafloor. As the canyon crosses the upper slope, its crosssectional area increases and it becomes $\mathrm{V}$-shaped. Large canyon cross sections, over $6 \mathrm{~km}$ wide and incised over $800 \mathrm{~m}$ below the surrounding seafloor, are observed south of the sharp bend the canyon makes at $22^{\circ} 03^{\prime} \mathrm{N}$ (see profiles MW9006-3 and
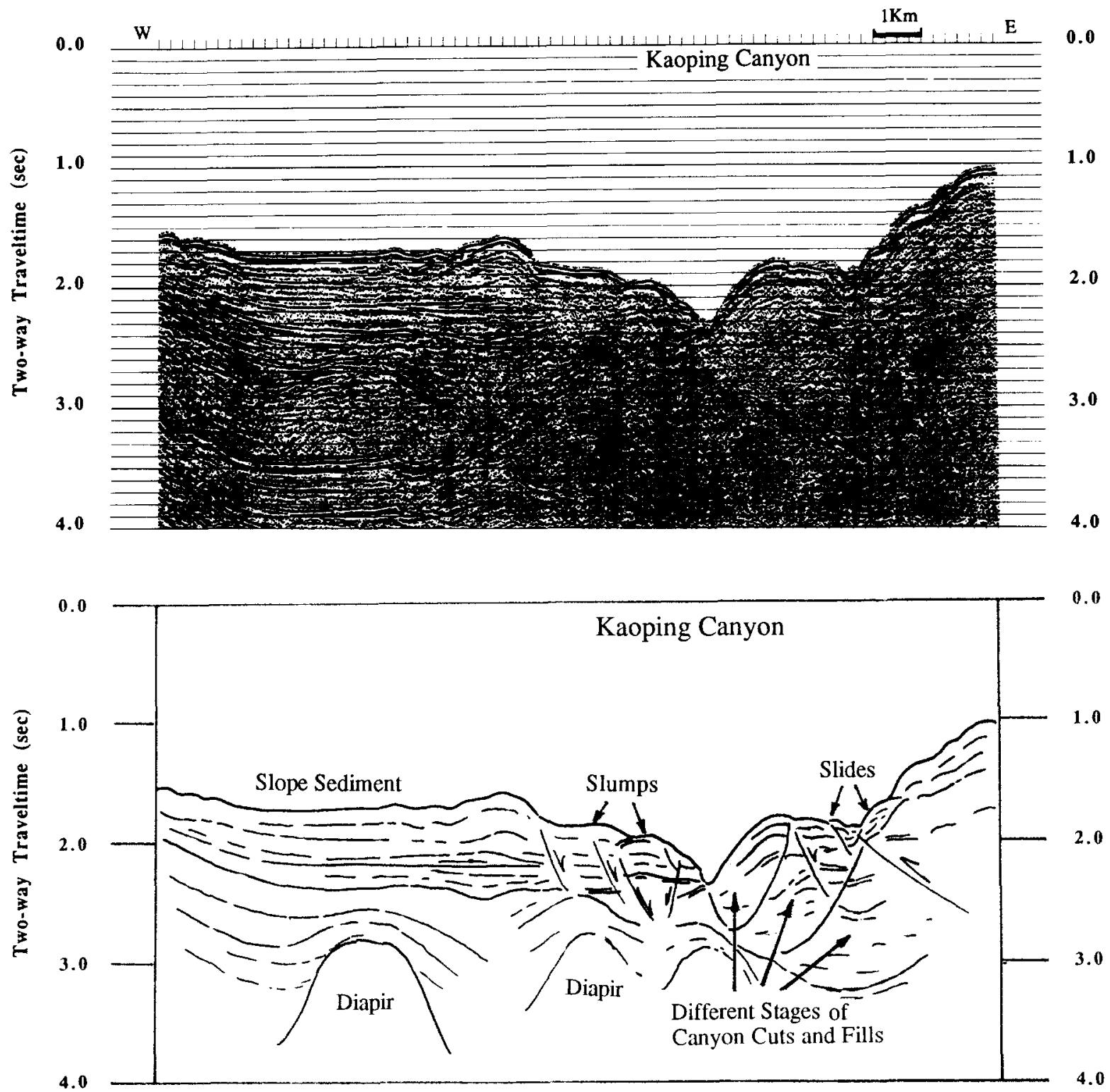

Fig. 7. Migrated six-channel seismic reflection profile (part of MW9006-2) crossing the Kaoping Submarine Canyon (see Fig. 5 for location). Present sedimentary processes of the canyon are mainly erosional, as shown by slides and slumps. At least three episodes of canyon cutting and filling can be identified. 


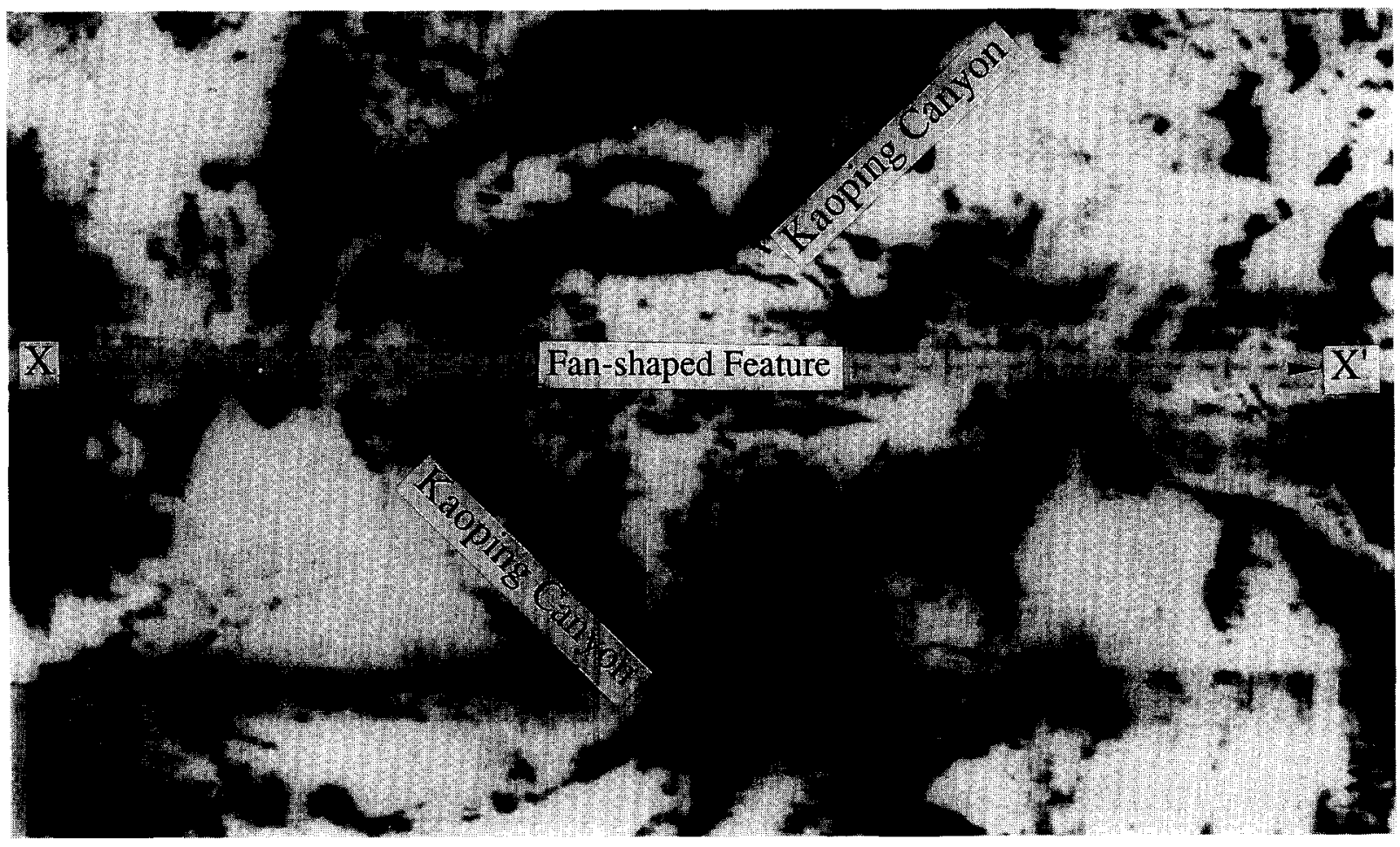

Fig. 8. SeaMARC II side-scan sonar image showing a canyon meander interpreted to have been induced by slumping and/or sliding (see Fig. 6 for location). $X-X$ ' indicates location of seismic reflection profile showing in Fig. 9.

MW9006-4 in Fig. 5). The shape of the canyon changes dramatically as it reaches the lower slope. It flows around small ridges as a broad and shallow meandering channel (profile MW9006-9 in Fig. 5), occasionally becoming deep where incising uplifted ridges (profile MW9006-17 in Fig. 5), until it reaches the Manila Trench.

A mosaic of the SeaMARC II side-scan sonar image over the Kaoping Submarine Canyon area and an interpretation are shown in Fig. 6. A distinguishing morphological character of this canyon is the apparent lack of both tributary channels and bifurcating branches over the course of the canyon. Two factors may contribute to this unique character: (1) the Kaoping Submarine Canyon is the submarine extension of a major river, the Kaoping River, on land; and (2) the Kaoping Submarine Canyon is situated on an active accretionary wedge, and tectonic structures provide the main control over the course of the canyon, as will be discussed in the next section.

In addition to the trace of the Kaoping Subma- rine Canyon, the SeaMARC II side-scan sonar mosaic reveals the distribution of linear ridges and faults, sediment slumps and sedimentary basins around the canyon. The relationship between the canyon morphology and surrounding structures can be identified by correlating multichannel seismic reflection profiles with the side-scan sonar images. Based on analysis of these data, we discuss structural variations and canyon development in the following section.

\section{Canyon development}

Because the Kaoping Submarine Canyon connects to a major river on land, the initiation of this canyon has been ascribed to subaerial erosion (Ma, 1963; Yu et al., 1991). Ma (1963) interpreted the bend of the Kaoping Submarine Canyon around the island of Liuchiu-Hsu (Fig. 2) as an indication that the canyon developed after formation of the upper Pleistocene coral limestone on Liuchiu-Hsu. Yu et al. (1991) suggested that the 

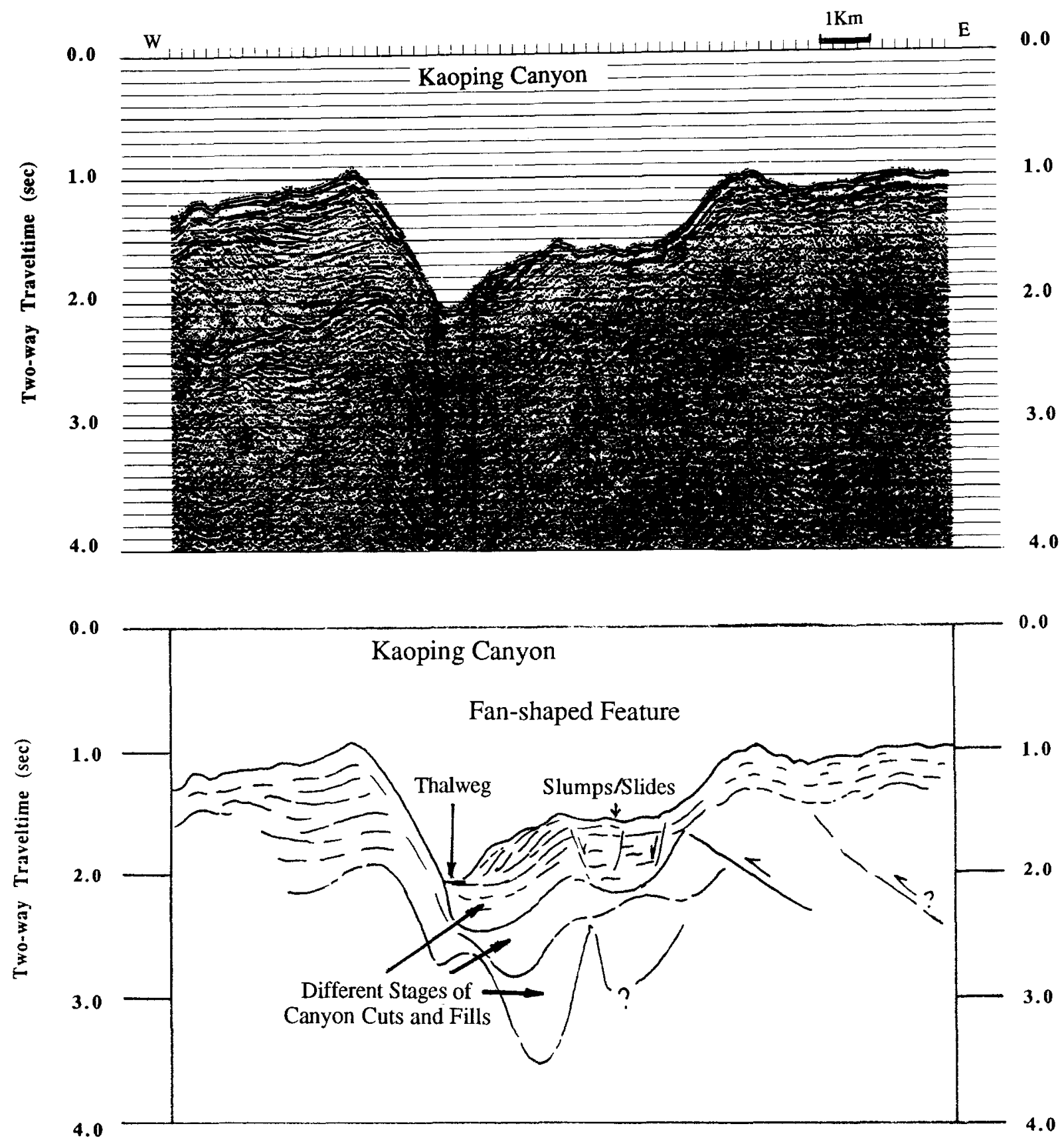

Fig. 9. Migrated six-channel seismic reflection profile (part of MW9006-1) crossing the Kaoping Submarine Canyon (see Figs. 5 and 8 for line location). Present thalweg is west of former canyon, which is now filled by slumps and/or slides.

Kaoping Submarine Canyon began cutting through shelf sediments in the late Pleistocene, at most about 15,000 years ago, based on the timing of the most recent lowering of sea level. Our seismic profiles reveal a very complicated canyon development history, however (discussed below), and we believe that the initial canyon incision is much older than 15,000 years. The Kaoping Submarine Canyon could well have formed by submarine processes in the early Pleistocene, because (1) 

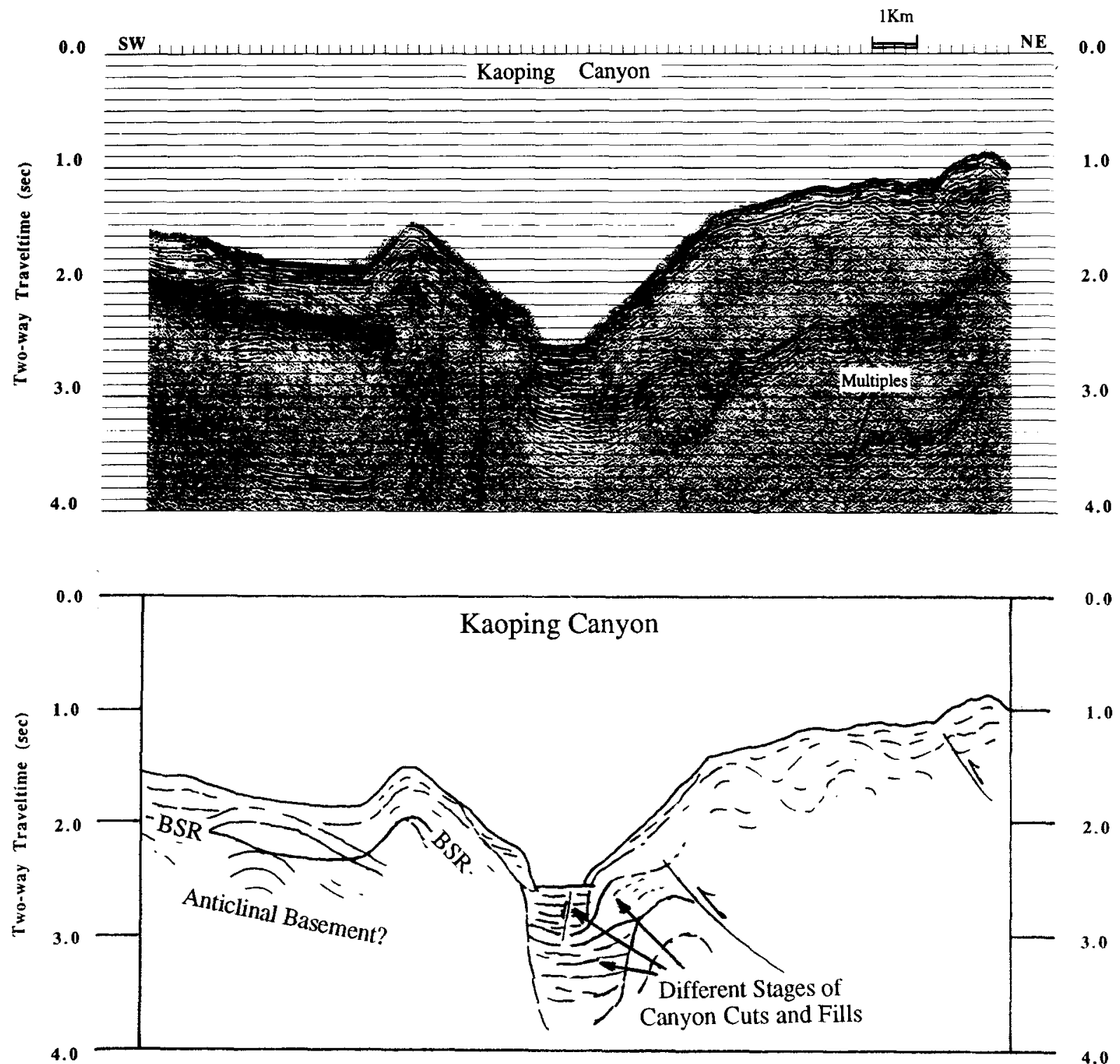

Fig. 10. Migrated 24-channel seismic reflection profile (part of MCS265-1) crossing Kaoping canyon (see Fig. 5 for location). Canyon is V-shaped, about $6 \mathrm{~km}$ and $825 \mathrm{~m}$ deep. Strong bottom-simulating reflections (BSR) obscure details of anticlinal structure. Present sedimentary processes within canyon are clearly erosional in this profile.

early Pleistocene submarine canyon lithofacies are observed in the southwestern Taiwan foothill region (Lin, 1991) not far from the up-stream portion of the Kaoping River, and (2) lower Pleistocene deltaic conglomerates are observed in the Kaoping River valley on land (Ho, 1988). Direct age control, however, is lacking.

In the upper reaches of the canyon we find evidence of submarine processes such as downcut- ting of the axial valley by submarine erosion and widening of the canyon by oversteepening, sliding, and slumping (Fig. 7), such as reported by Andrews and Hurley (1978). Complex cuts and fills observed in sedimentary sequences beneath the present canyon floor clearly indicate that the upper section of the canyon has experienced several stages of erosion and deposition. The shape of the canyon has been influenced by both thrust and 


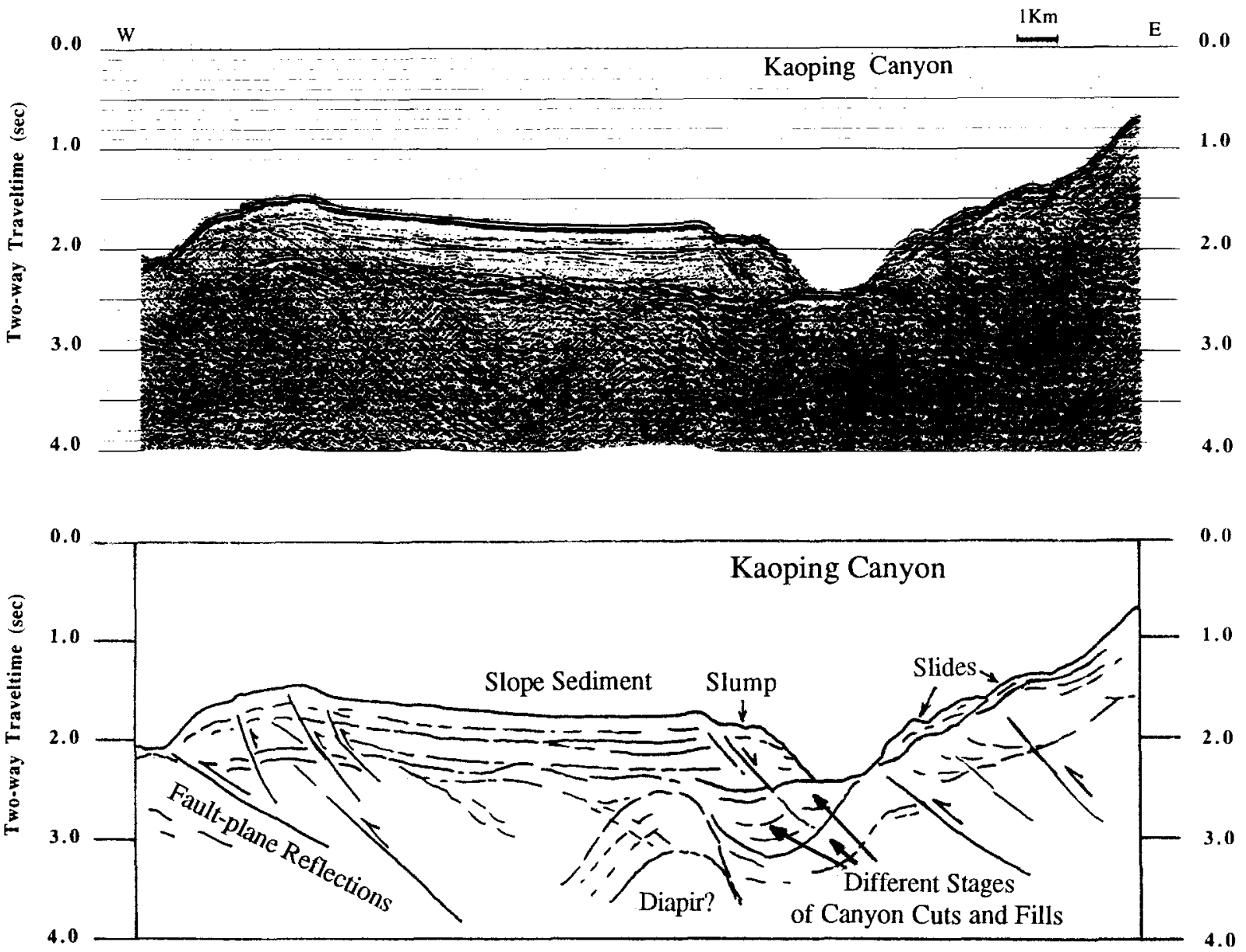

Fig. 11. Migrated six-channel seismic reflection profile (part of MW9006-7) crossing Kaoping Canyon (see Fig. 5 for location). Note west-vergent thrust fault that reaches seafloor at eastern side of canyon floor. Buried former canyon was apparently much larger than present canyon in this profile.

normal faults, the former due to regional compression and the latter due to local slope failure and mass movement processes. Large slumps and slides may even have forced the canyon to change its course. A high-resolution side-scan sonar image (Fig. 8) shows that in one location on the upperslope area the canyon turns sharply and circles around a fan-shaped feature. A seismic reflection profile across this area (MW9006-1) shows that a filled canyon lies underneath the eastern half of the fan-shaped feature (Fig. 9). This canyon may have been filled rapidly by large slumps or slides, forcing the canyon to change course and detour around the slided material. We interpret dipping reflectors seen in the western half of the fan-shaped feature as sediment deposited by meandering canyon. The canyon thalweg has apparently migrated westward, eroding its western margin while depositing sediment along its eastern margin (Fig. 9). Previous episodes of cutting and filling can also be identified on seismic profiles across the canyon in this region.

In additional to the sedimentary processes described above, the path of the Kaoping Submarine Canyon has been influenced strongly by tectonic structures. A major bend in the course of the canyon at about $22^{\circ} 03^{\prime} \mathrm{N}$ (location B in Fig. 3) is caused by a ridge that blocks the southwestly course of the canyon, diverting it to the southsoutheast (Fig. 6). This ridge may be located over 


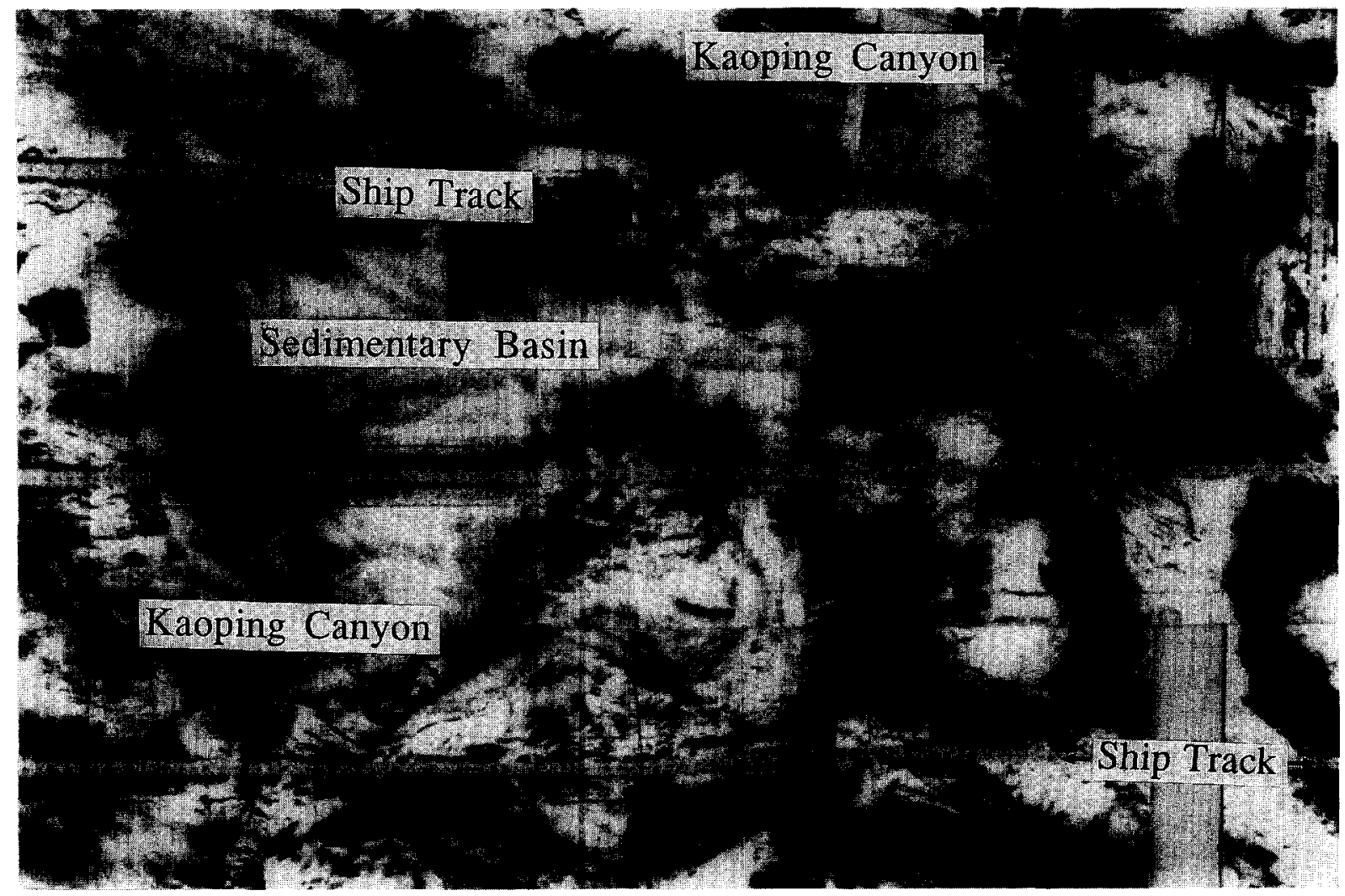

Fig. 12. SeaMARC II side-scan sonar mosaic, showing distribution of sediment deposited from Kaoping Submarine Canyon at base of upper slope (see Fig. 6 for location). Canyon becomes broad, meandering channel on lower slope.

a basement high, because large positive gravity and magnetic anomalies are observed over the ridge and the area immediately west (S.-Y. Liu, pers. commun., 1992). A seismic profile across the canyon just south of this turn (Fig. 10) shows a strongly asymmetric buried canyon, suggesting that the material beneath the ridge west of the canyon is much more resistant than that to the east of the canyon. Unfortunately, a strong bottom-simulating reflector (BSR) has made details of the anticlinal feature uncertain (Fig. 10).

From this bend in the course of the canyon to the next major bend at about $21^{\circ} 35^{\prime} \mathrm{N}$ (location $\mathrm{C}$ in Fig. 3), the canyon flows along the trace of a west-vergent thrust fault, which can be observed clearly on seismic profiles (Fig. 11). Immediately west of the canyon in this region is a moderately thick section of slope sediment, which may have been transported here by the Kaoping Submarine Canyon. The present sedimentary processes in this section of the canyon are mainly erosional, however, as indicated by sliding, slumping, and normalfaulting of the canyon walls (Fig. 11).

At about $21^{\circ} 35^{\prime} \mathrm{N}$, where the canyon flows near the base of the upper slope, a ridge to the south blocks the south-southeasterly course of the canyon. The canyon turns southwesterly, cuts through a low-relief anticlinal ridge, and reaches the lower slope (Figs. 3 and 6). We infer that the sediment cover that blankets a large area here was carried by the Kaoping Submarine Canyon (Figs. 12 and 13). In this area, the canyon becomes a broad, shallow, meandering channel and flows around and through low-relief fault-bend folds of the lower slope (Fig. 13). The regional stress field is compressional, as indicated by the west-vergent thrust faults beneath the ridges. Normal faults observed within the thick sedimentary column may result from differential compaction of rapidly deposited sediment. Buried canyon-fill sequences, 

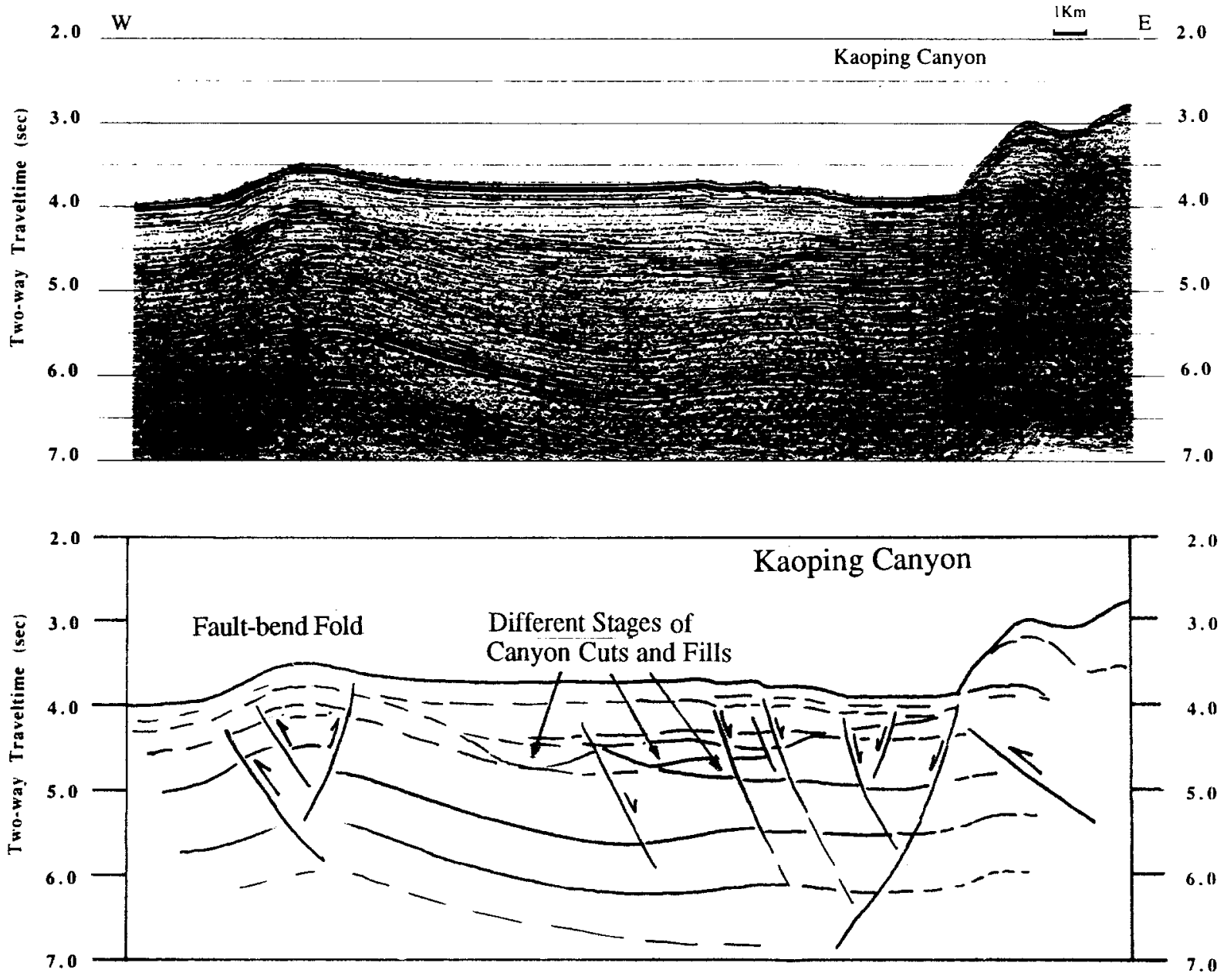

Fig. 13. Migrated six-channel seismic reflection profile (portion of MW9006-9) crossing Kaoping Submarine Canyon at base of upper slope (see Fig. 5 for location). Canyon becomes very shallow and broad here. Up to $0.7 \mathrm{~s}$ (two-way traveltime) of uppermost strata has been deposited in this slope basin, ponded behind fault-bend fold to the west. Buried cut and fill sequences indicate former locations of meandering canyon.

observed on seismic profiles, reveal former courses of the canyon. Finally, at the toe of the accretionary wedge, the canyon becomes small and shallow (Fig. 14), until its morphologic expression disappears near the Manila Trench (Fig. 15).

\section{Present-day distribution of orogenic sediment}

The longitudinal profile of the Kaoping Submarine Canyon axis shows two segments of distinctly different surface slope, with a steep gradient across and along the upper slope and a gentle gradient across the lower slope. Although seismic profiles document a complicated history of canyon development, the present sedimentary processes of the Kaoping Submarine Canyon in the upper-slope area are mainly erosional (Figs. 7, 9-11), whereas those in the lower-slope area are mainly depositional (Figs. 13 and 14). The first major area of present-day deposition of sediment transported by the canyon begins at the base of the upper slope, where side-scan sonar mosaics and seismic profiles show thick and extensive sedimentary sequences in slope basins. Some of the sediment carried past this region by the Kaoping Submarine Canyon is distributed as overbank deposits along its mean- 

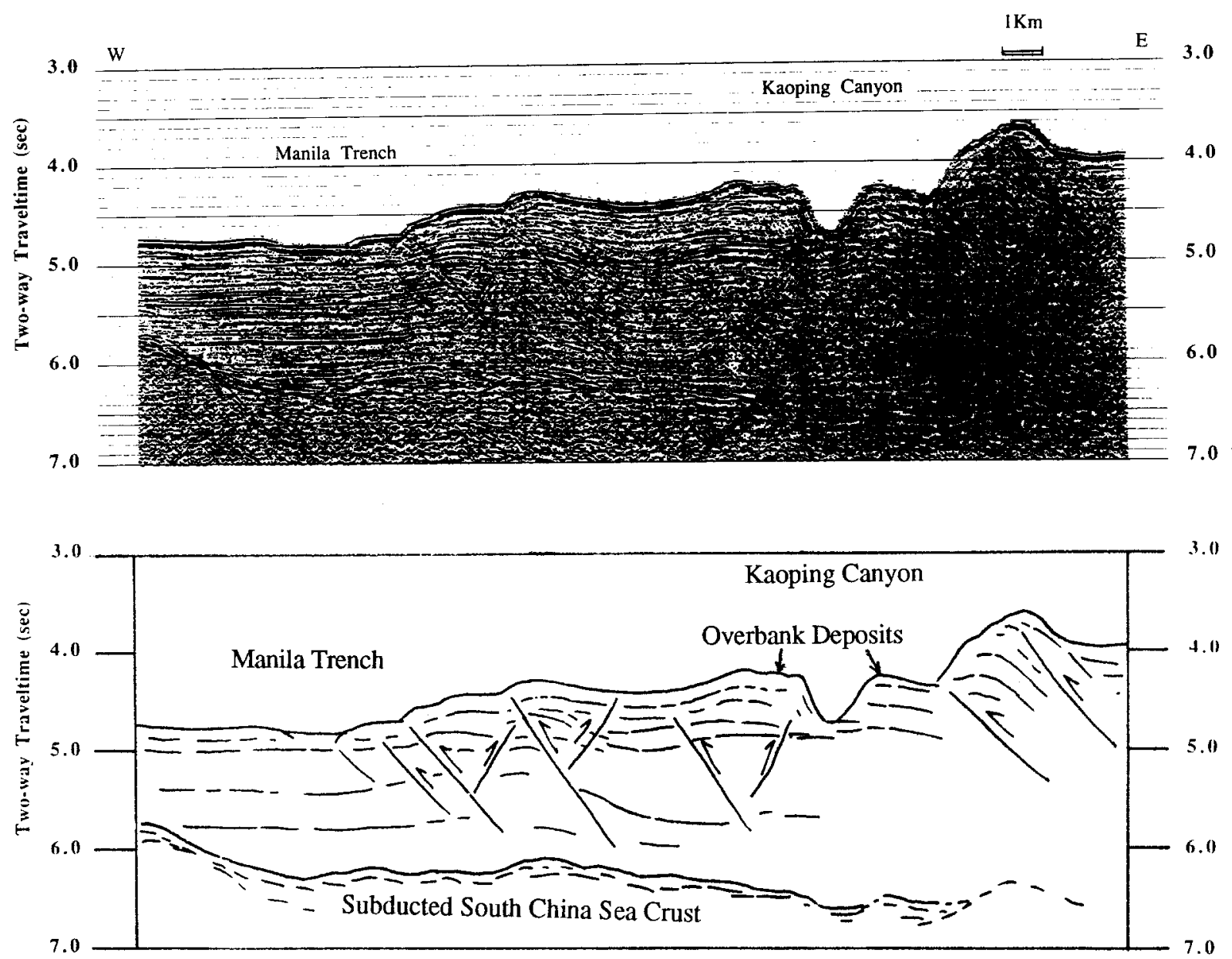

Fig. 14. Migrated six-channel seismic reflection profile (portion of MW9006-17) across Kaoping Submarine Canyon on lower slope (see Fig. 5 for location). Overbank deposits along both flanks of canyon indicate active deposition. Canyon may be bounded to west by east-vergent thrust fault, in addition to west-vergent thrust to east.

dering course over the lower slope, and the rest enters the Manila Trench. A local submarine fan is developing where the Kaoping Submarine Canyon joins the Manila Trench, but it is likely that some sediment is also carried further, transported longitudinally southward along the Manila Trench (Fig. 15).

\section{Conclusions}

SeaMARC II side-scan sonar images and swath bathymetry data reveal a major submarine canyon on the active accretionary wedge off southwest Taiwan. The Kaoping Submarine Canyon, which previously had been identified only relatively near (within $40 \mathrm{~km}$ ) the mouth of the Kaoping River, extends from the river mouth all the way to the Manila Trench, with a total length of over $240 \mathrm{~km}$. Our data show that the Kaoping Submarine Canyon follows a complicated path, crosscutting morphotectonic structures in portions of the accretionary wedge and trending parallel to structures in other areas.

The Kaoping Submarine Canyon was probably not initiated by subaerial erosion as previous studies have suggested. Our study indicates that the canyon is more likely to have formed by submarine processes and could have been in existence since the early Pleistocene. Multichannel seismic reflection profiles and $3.5 \mathrm{kHz}$ profiles 


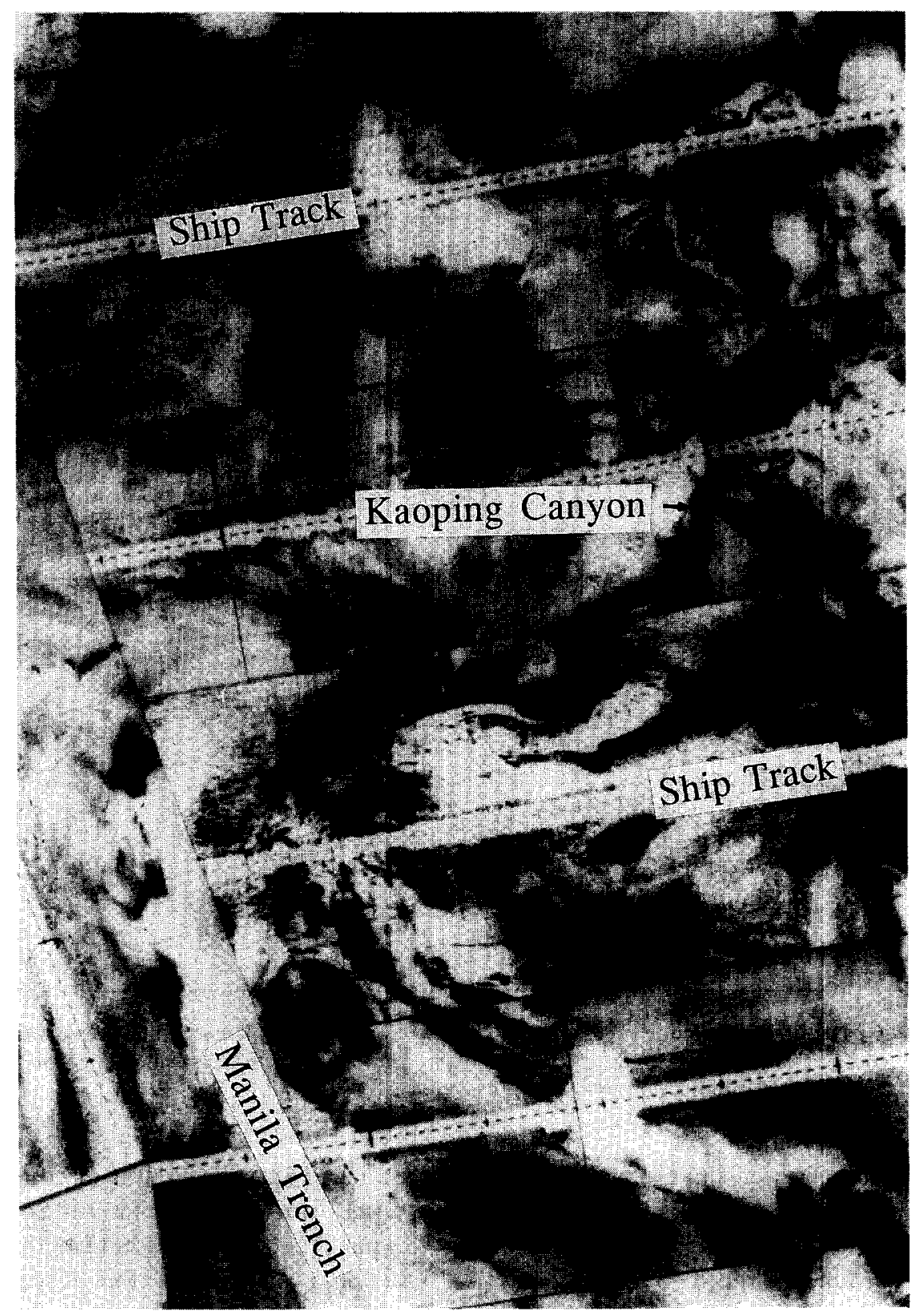

Fig. 15. SeaMARC II side-scan sonar mosaic showing Kaoping canyon emptying into Manila Trench (see Fig. 6 for location). Depositional lobes and southward flow pattern of sediment can be seen clearly.

show that submarine erosional processes here played an important role in shaping headward portions of the canyon, which incise the upper slope. However, active tectonic processes may be more important to the development of this canyon, as indicated by the distinctive shape of its overall course.
The course of the Kaoping Submarine Canyon can be divided into three sections, defined by two major bends that are controlled by tectonic structures. The first section runs roughly normal to bathymetric contours, from the mouth of the Kaoping River to a water depth of about $1800 \mathrm{~m}$, and is characterized by a relatively small, $\mathrm{U}$-shaped 
canyon. This section resembles many submarine canyons that have been well documented along passive continental margins. Seismic priofiles show that this canyon has experienced at least three episodes of canyon cutting and filling, suggesting the persistence of channel-forming mechanisms. The second section of the canyon is V-shaped and runs nearly straight for about $80 \mathrm{~km}$, along the trace of a thrust fault, to a water depth of about $2800 \mathrm{~m}$. A large amount of sediment has been deposited where the canyon reaches the base of the steeper upper slope, at the second major bend of the canyon path. The third section of the canyon meanders southwesterly across low-relief faultbend folds of the lower slope to join the Manila Trench at a water depth of about $3500 \mathrm{~m}$.

The Kaoping Submarine Canyon plays an important role in transporting orogenic sediments southwestward from Taiwan mountain belt to the Manila Trench. Because it has developed over an active accretionary wedge, the evolution of this submarine canyon is more complex than most submarine canyons located along passive continental margins. To further understand the evolutionary history of the Kaoping Submarine Canyon and distribution of sediment along the canyon path, lithologic analysis and age constraints based on coring and/or drilling are needed.

\section{Acknowledgments}

We thank the Captains and crews of the $\mathrm{R} / \mathrm{V}$ Moana Wave and the R/V Ocean Researcher I for their help in data acquisition. We thank A.N. Shor and technical staff of the Hawaii Institute of Geophysics for a very successful research cruise. L.S. Teng, H.S. Yu, J.R. Curray and two anonymous reviewers provided constructive discussions and/or comments. S.Y. Liu and S.W. Lee helped prepare some of the figures. This study presents part of the results of a joint research project and was supported by the National Science Council, ROC (NSC79-0209-M002A-14 and NSC80-0202M-002A-01 to C.S. Liu) and the National Science Foundation, USA (OCE-8911507 to N. Lundberg, D. Reed and A. Shor).

\section{References}

Andrews, J.E. and Hurley, R.J., 1978. Sedimentary processes in the formation of a submarine canyon. Mar. Geol., 26: M47-M50.

Big, C.C., 1973. Kinematic pattern of Taiwan as an example of actual continent-arc collision. Rep. Seminar Seismology, US-ROC Cooperative Science Program, pp. 21-26.

Bowin, C., Lu, R.S., Lee, C.S. and Schouten, H., 1978. Plate convergence and accretion in Taiwan-Luzon region. Am. Assoc. Pet. Geol, 62: 1645-1672.

Buchovecky, E.J. and Lundberg, N., 1988. Clay mineralogy of mudstones from the southern Coastal Range, eastern Taiwan: Unroofing of the orogen versus in-situ diagenesis. Acta Geologica Taiwanica, 26: 247-261.

Carlson, P.R. and Karl, H.A., 1988. Development of large submarine canyons in the Bering Sea, indicated by morphologic, seismic, and sedimentologic characteristics. Geol. Soc. Am. Bull., 100: 1594-1615.

Dorsey, R.J., 1992. Collapse of the Luzon volcanic arc during onset of arc-continent collision: Evidence from a Miocene-Pliocene unconformity, eastern Taiwan. Tectonics, 11: 177-191.

Goodwin, R.H. and Prior, D.B., 1989. Geometry and depositional sequences of the Mississippi Canyon, Gulf of Mexico. J. Sediment. Petrol., 59: 318-329.

Ho, C.S., 1982. Tectonic evolution of Taiwan: Explanatory text for the tectonic map of Taiwan. Central Geol. Surv., Minist. Econ. Aff., Taipei, 126 pp.

Ho, C.S., 1986. A synthesis of the geologic evolution of Taiwan. Tectonophysics, 125: 1-16.

Ho, C.S., 1988. An introduction to the geology of Taiwan: Explanatory text of the geologic map of Taiwan. Central Geol. Surv., Minist. Econ. Aff., Taipei, 2nd ed., 192 pp.

Huang, C.Y., Shyu, C.T., Lin, S.B., Lee, T.Q. and Sheu, D.D., 1992. Marine geology in the arc-continent collision zone off southeastern Taiwan: Implications for late Neogene evolution of the Coastal Range. Mar. Geol., 107: 183-212.

Karig, D.E., 1973. Plate convergence between the Philippines and the Ryukyu islands. Mar. Geol., 14: 153-168.

Lin, D.S., 1991, Lithofacies and the sedimentary environment evolution of the Plio-Pleistocene series in the southwestern Taiwan foothills region. M.S. Thesis, Natl. Taiwan Univ., 93 pp. (in Chinese).

Lundberg, N., Reed, D.L., Liu, C.S., Kuo B.Y., McIntosh, K.D., Lieske, J.H., Jr. and Shor, A.N., 1990. Tectonics and sedimentation across the actively propagating are-continent collision of Taiwan. EOS, Trans. Am. Geophys. Union, 71: 1562 .

Lundberg, N., Reed, D.L. and Liu, C.S., 1991. The submarine propagation tip of the Taiwan collision: Shallow crustal structure and orogenic sedimentation. In: C.T. Shyn, C.Y. Huang and Y.T. Yeh (Convenors), Proc. TAICRUST Workshop, Natl. Taiwan Univ, Taipei, pp. 93-102.

Ma, T.Y.H., 1947. Submarine valleys around the southern part of Taiwan and their geological significance. Bull. Oceanogr. Inst. Taiwan, 2: 1-12.

Ma, T.Y.H., 1963. Twin origin of the submarine canyons around Taiwan and the Quaternary glaciation in Taiwan as basis for refutation of the turbidity current theory and the 
so-called "great ice age" as due to universal lowering of temperature. Pet. Geol. Taiwan, 2: 209-219.

McGregor, B.M., Stubblefield, W.L., Ryan, W.B.F. and Twichell, D.C., 1982. Wilmington Submarine Canyon: A marine fluvial-like system. Geology, 10: 27-30.

Nagel, D.K., Mullins, H.T. and Greene, H.G., 1986. Ascension Submarine Canyon, California-Evolution of a multi-head canyon system along a strike-slip continental margin. Mar. Geol., 73: 285-310.

Reed, D.L., Lundberg, N., Liu, C.S., McIntosh, K.D., Leiske, J. and Kuo, B.Y., 1991. Strain domains, fluid/gas migration and protothrusting in the offshore Taiwan accretionary wedge. Geol. Soc. Am. Abstr. Progr., 23: A365.

Shepard, F.P., 1981. Submarine canyons: Multiple causes and long-time persistence. Bull. Am. Assoc. Pet. Geol., 65: 1062-1077.

Shepard, F.P. and Emery, K.O., 1973. Congo Submarine
Canyon and fan valley. Bull. Am. Assoc. Pet. Geol., 57: 1679-1691.

Suppe, J., 1984. Kinematics of arc-continent collision, flipping of subduction and back-arc spreading near Taiwan. Geol. Soc. China, Mem., 6: 21-33.

Suppe, J., 1987. The active Taiwan mountain belt. In: J.P. Schaer and J. Rodgers (Editors), Comparative Anatomy of Mountain Ranges. Princeton Univ. Press, pp. 277-293.

Teng, L.S., 1990. Geotectonic evolution of late Cenozoic arccontinent collision in Taiwan. Tectonophysics, 183: 57-76.

Yabe, H. and Tayama, R., 1928. A cartographical study of the submarine relief of the Strait of Formosa. Rec. Oceanogr. Works Jpn., 1: 97-101.

Yu, H.S., Huang, C.S. and Ku, J.W., 1991. Morphology and possible origin of the Kaoping Submarine Canyon head off southwest Taiwan. Acta Oceanographica Taiwanica, 27: $40-50$. 